\title{
The Real U.S. Role and Position in the World Economy
}

\author{
Rolf Hackmann \\ College of Business and Technology, Western Illinois University \\ 1 University Circle, Macomb IL 61455, USA \\ Tel: 1-309-298-1629Ｅ-mail: R-Hackman@wiu.edu \\ Xiang Yi (Corresponding author) \\ College of Business and Technology, Western Illinois University \\ 1 University Circle, Macomb IL 61455, USA \\ Tel: 1-309-298-1997Ｅ-mail: X-Yi@wiu.edu \\ Anna Valeva (Corresponding author) \\ College of Business and Technology, Western Illinois University \\ 1 University Circle, Macomb IL 61455, USA \\ Tel: 1-309-298-1403Ｅ-mail: AK-Valeva@wiu.edu
}

\begin{abstract}
This paper proposes a new method of measuring the position of the United States in the world economy defined by the GDP standard as before. The central argument is that previous approaches relied solely on measuring position on the basis of geography. GDP produced on American soil, including its export and import components, were indiscriminately considered to be "American". More realistically, the measurement of the U.S. economic power needs to be adjusted for the foreign element in local production, imports and exports. More specifically, the role of majority-owned foreign direct investment enterprises within the U.S., as well as their U.S. corollaries abroad, needs to be explored. Thus, the real economic size of a nation can be precisely measured on the basis of capital control rather than national geography, which now loses any meaningful reference role altogether. Substituting this new approach also allows for a more realistic, direct assessment of national competitiveness in the global economy. The step-by-step implementation and consequences are explained in the paper. Ultimately, national competitiveness is determined by the relative trend developments of the outward versus inward direct investment forces.
\end{abstract}

Keywords: Foreign direct investment, Capital ownership, Majority-owned affiliates, U.S. international trade, National competitiveness, Globalization

\section{Introduction}

The following discussion advances a new concept for the definition and measurement of international competitiveness. It is felt that the present method of comparing national accounts of geographically defined national entities is inadequate, because national influence in the world economy is no longer determined by political geography, but by national capital control over business activities dispersed throughout the world. The globalization of national economies via expanding direct investments has caused significant changes in national roles and positions in global output of goods and services as well as international trade. These changes require special recognition, if the transformation from strictly national industries into global players is to become transparent and fully understood.

Instead of solely continuing with this geographically inspired model for historic reasons, it is thus proposed to introduce capital ownership as the defining criterion for national influence and control over economic activities in a global economy. Capital can be furnished in two forms: foreign direct investments (FDI), and portfolio investments. As the latter is sufficiently different in character from the former, in that it does not aim at control over marketing organizations in a broadest sense, and their activities, it is excluded from further discussion here.

Under the traditional view of the economic world the label "Made in ..." correctly identified the national origin of products, because three elements coincided: national territory, ownership of productive resources, and the 
decision power over their disposition. Today, this view is not matching reality, as global companies progressively integrate the global economy, in which the national state appears more and more as a historical footnote.

Business interests with a clearly defined national origin project their nationality into foreign countries when conducting international business activities. By capital ownership and central control over business decisions they remain an integral part of their parent organizations and thus the country of origin. As such, they project their original nationality into foreign territories. Decisions about what to produce and trade are not made at the subsidiary level. They are dictated by parental boardroom fiat, which clearly separates control from national territory of manufacture, distribution, and consumption. Absentee capital control and locus of decision are moving into the foreground, and thus establish a product's "nationality", with the geography of manufacture and shipment becoming only an incidental aspect.

The progressive liberalization and accessibility of global markets changes the ways of and outlook on international marketing efforts. The historic view was shaped by an export-oriented mentality, which attached lesser importance to full control over marketing activities beyond national territory all the way up to foreign end users or consumers. By contrast, FDI emphasizes 100 percent control over the delivery of marketing efforts up to the end market, full and direct ownership of the market share attained with company products and, at least, partial and legal ownership of the national economy where the affiliates are located. Exports are still important, but secondary to the fully integrated marketing strategy. The emergence of foreign affiliate production and marketing structures also accounts for a growing FDI share in world trade. FDI is the direct extension of a private enterprise into the global market seeking a comparable degree of control over foreign markets to the one it enjoys at home.

Control now rests on the capital base established in world markets. From a legal point of view such company is considered a part of the nation of domicile. From the capital ownership and control point-of-view, it definitely is a foreign business entity, whose nationality is determined by the principle of majority share held in the total capital invested and management control. Majority-owned foreign affiliates (MOFAs) make this a clear-cut case, and present little difficulty in accepting the national origin of capital as the determining criterion of a subsidiary's nationality in preference over the geographical location of the enterprise. The following analysis is an attempt to demonstrate the usefulness of the new concept for the determination of national competitiveness. It proceeds from the traditional, territorial concept of a national economy, to the gradual transformation into the model based on capital control. For convenience's sake, the example of the U.S. is used, but the principle may be extended to any national economy. Substituting national capital control for geographically defined business ownership enhances the view and appreciation of the true American-controlled share of the world economy.

The measurement of national competitiveness in this macro-economic fashion is strictly limited, for now, to trend observations of broad industrial sectors as far as U.S. FDI in foreign markets is concerned for two reasons. One is that international databases and statistical methods are not yet sufficiently standardized to allow for more detailed presentations. The other is that FDI activities rarely extend into the public sector of national economies, and their inclusion could lead to grave distortions.

The proposed concept works in opposite ways. American capital flows from the territorial U.S. to other world areas tend to increase the American share in the world market and global trade by means of direct capital ownership over both as explained. The influx of foreign capital into the U.S., on the other hand, has the tendency to erode that share. In the ultimate analysis, national competitiveness is thus determined by the relative trend developments between these two forces.

\section{The Global Market}

All the ongoing discussion about a global market has yet to produce a clear picture of its actual size, composition, and development trends. The problem lies in the availability, comparability, and reliability of national statistics which, despite the commendable pioneer work of supra-national or international organizations like the European Community, OECD, IMF, and the World Bank, still lack the desirable degree of standardization and uniformity.

A major contributor to the problem is the existing plethora of national currencies with ever-fluctuating exchange rates, lack of annually updated time series for macro-economic data, mixtures of preliminary and final data, etc. The use of the U.S. dollar as the international standard of measurements guarantees U.S. economic data to be reported reliably and in a meaningful way for a big part of the global economy. But it also adds to grave uncertainties and outright distortions of economic facts and trends in other currency areas as all students of the subject can attest.

Thanks to the World Bank a much needed and useful picture of the world market begins to take shape as 
provided in Table 1. The original data have been grouped into four areas, the U.S., Europe, Japan, the Triad economies, and all others.

The U.S. share in this traditional view of the world market, composed of the public and private sector GDP, is consistently large and ranges between 24-36 percent. According to this source of information the U.S. economy was in first place for almost the whole period, with Europe in second, except for 1979-80, and 1992, when Europe surpassed the U.S., however, not by much. In making this comparison one has to keep in mind that the European figures are heavily affected by the strong relative movements of all currencies involved. The dollar moved up strongly between 1980 and 1985, which is correctly reflected in the rising U.S. share. Its decline after 1985 laid the foundation for a somewhat weaker U.S. position in the world output of value added until the fluctuations of the Euro (introduced on January 1, 2002) added more volatility.

The data indicate that Europe as a whole has clearly fallen behind the U.S. Taken at face value, they raise a question about the consistent nature of international statistics. Logic would demand the establishment of Europe in first place with the modernization of former communist economies upon entering the EU, which has now grown to 25 member states.

\section{[Table 1 is about here]}

Japan's progress over the years against the U.S., as well as Europe, is phenomenal, and fully confirms the competitive image of that nation. From a share of around 20 percent of the U.S. and 33 percent of European gross product in 1970, Japan has been able to advance especially dramatically in 1986-2000 to ranging 45-71 percent of the U.S. and 53-75 percent of the European gross product, stabilizing down to 34 percent of the U.S. and 36 percent of the European gross product in 2008. The rest of the world is about equal in economic weight to the U.S. from the mid 1980s until 2002, but beginning with 2003 there is a decisive acceleration in its growth rate and critical mass, which will eventually carry it way beyond the traditional economic giants referred to as the Triad economies.

At this moment, China and India are the motors of growth in the developing world. Other nations in Asia are joining in, and the wheel of unstoppable progress is already rolling towards Africa and South America. The importance of this budding exuberance for the Western world cannot be overlooked. The developed world of today will go into a relative decline vis-à-vis these younger economies.

This preliminary scenario sets the stage for the next steps of moving away from the view of the world economy as the sum total of individual country economies in the traditional geographical interpretation. Now, the focus can shift to a new appreciation of national weight in the world economy under the aspect of capital control and ownership across the same market without the distraction of national boundaries.

\section{Foreign Direct Investment (FDI) and the U.S. Economy}

FDI is the rapidly growing market share strategy joining its older sibling exports for building solid and lasting footholds in the world economy. It has the big advantage over the latter of offering direct influence and control over foreign markets, and often even countries, not possible with trading activities alone.

For the purpose of this investigation three questions have to be addressed. The first concerns the size of the U.S. national economy in relation to all others in the traditional, geography-centered definition. It has been addressed and answered in Table 1. Since 1970 the U.S. share of the global economy, by this definition, has oscillated between $24-36 \%$.

The second question concerns the more sensitive aspect of how inward FDI, or tangible foreign ownership, has reduced and is continuing to reduce the national ownership proper of economic resources and output in the U.S. In other words, how much of the U.S. economy is actually owned and operated by majority-held enterprises in foreign hands?

The logical next and final question addresses to what extent foreign inroads into the American economy have been off-set by developments of U.S. outward FDI, the share-building effort in the world economy. Both inward and outward direct investments are engaged in a competitive struggle for market share here. As long as one side can consistently stay ahead of the other, it is the winner in this competition. However, the absolute position alone is only one aspect of measuring both sides. What really counts is the relative speed at which both contestants advance against each other.

In other words, questions two and three change the focus from measuring economic output in a national territory to nationally controlled output within the world economy irrespective of political boundaries. Taking this point one step further by studying the relative development speeds of outward vs. inward FDI activities allows fairly 
accurate prognostications about a nation's course in the international competition. Presently, the attention paid to the development of exports from a national territory as another legitimate measure of national economic weight in the world, clouds the vision for the importance of FDI in determining a nation's true economic stature in the global market. Two figures will drive this point home. All American merchandise exports amounted to $\$ 806.2$ billion in 2004 (Economic Report of the President, 2010c), which amounted to less than one fourth of the \$3.3 trillion sales volume, (see Table 2), generated by U.S. majority-owned outward FDI enterprises that year. Impressive as U.S. exports appear, they do not come close to matching the earnings power of American overseas enterprises; especially not if it is realized that $\$ 155.5$ billion (BEA, 2007), i.e., about 19 percent of those exports are in the hands of foreign majority-owned nonbank affiliates in the U.S.

Table 2 gives some insight into the issues addressed by questions two and three. While in absolute terms U.S. outward FDI exceeds the numerical values of like inward FDI dimensions on all counts, foreign business interests operating in the U.S. have invested more rapidly here than U.S. FDI businesses have abroad. As a result, the foreign direct investment position in the U.S. grew from 24 percent of the U.S. outward FDI position in 1977, to 72 percent in 2007. Similar advances are registered for sales from 38 to 65 percent between 1977 and 2007. In the same time span, employment rose from 17 to 54 percent, gross product from 22 to 57 percent, and assets from 29 to 66 percent. However, we have to note the consistent decline in the relative size of the inward FDI activities since their peak in 2000-2001 that has gradually occurred with the slowdown of the U.S. economy and the acceleration of the growth rate of economies outside the Triad ones.

\section{[Table 2 is about here]}

Had it not been for the virtual stagnation of America's outward FDI activities for most of the 1980s, it would have been difficult for inward U.S. FDI to gain as rapidly against its U.S. rival. Curiously, most of their growth came from their penetration of the manufacturing sector which at that time was downplayed with such pejorative terms as smokestack or rustbelt industries by the U.S. business community and public. American investment interest at home centered on service industries with higher and thus more promising growth rates.

A curious aspect of U.S. outward FDI is the fact that total employment practically stagnated between 1977 and the mid-nineties despite a quadrupling of their investment volume and an estimated tripling in sales. As the investment position and assets grew faster over the period, this means that the capital intensity per employee has been increasing rapidly. The trend in capital buildup is even more pronounced for inward investors such that in 2000 outward investments concentrated $\$ 161,082$ per employee vs. $\$ 222,185$ per employee for inward investors, a 38 percent difference.

A somewhat smaller, but still remarkable 28 percent difference is also visible in comparing assets/employee of $\$ 580,749$ for U.S. outward FDI against $\$ 745,324$ for the inward side.

Table 2 also shows a stagnation bordering on slow decline in inward employment for 2001-2007, while there is a steady increase in inward investment and assets growth. Outward employment for the same period grew slowly together with outward investments and assets. As a result, the capital buildup per employee remains more pronounced for inward investors. For 2007, the last year for which complete data are available, outward investments amounted to $\$ 291,195$ per employee vs. $\$ 390,289$ per employee for inward investors, a 34 percent difference, and assets/employee of $\$ 1,315,783$ for U.S. outward FDI against $\$ 1,615,779$ for the inward side, a 23 percent higher level, which also constitutes a significant jump (about 15 percent) from the preceding three years.

The 2000 sales output per employee displays lesser variations. Sales of $\$ 306,866$ per outward employee contrast with $\$ 362,719$ for each inward employee, an 18 percent higher level. The economic implications of the 38 percent higher capital investment yielding only an 18 percent higher sales output per employee for foreign investors in the States are difficult to explain without further studies. Curiously enough, the difference between investments per employee and sales per employee buildup almost disappears in 2002 and 2004, while a smaller, although still considerable difference of about 12 percent remains during 2005-2007.

Another difference worth mentioning is the output of value added by both investor types. Outward investment produced a 48 percent margin on sales of $\$ 2,507.4$ billion in 2000 compared to only a 39 percent margin for all inward majority-owned affiliates in the States. After a short period of decrease in the variability of outward vs. inward margin on sales during 2002-2004, the variability remains at about 6 percent higher margin for inward sales for the last three years of available data. This is a significant variation that can be partially explained with different structures of gross profits generated in both world areas. Employee compensation and profit-type components drive the inward investment results, whereas indirect business taxes and related factors predominate in the generation of the outward investment value added. It may also be that similar profit policies by both investor types are involved here. In order to escape the American tax bite both are aiming at maximizing their 
profits outside the U.S. where they can be legally sheltered in many different tax heavens.

\section{Dimensions of U.S. Outward FDI}

The main features of the American-related FDI activities are captured in Table 3. Comparing this information to similar data by major world regions is made possible thanks to the GDP information put together by the World Bank and shown in Table 1.

In addition, useful perspectives can be developed by comparing outward FDI affiliates with the industrial segment of the U.S. economy itself, exclusive of agriculture and government. Limiting the comparison in this manner is appropriate, in-as-much as majority-owned U.S. affiliates do not engage in agricultural businesses and definitely not in the public sector.

The decline of MOFA data against their home country data is significant when measured against the base year 1977. But the visible weakness in the eighties and nineties may have ended in the early 2000s with a rebound in the share data closer to the beginning level.

The decided slowdown in U.S. direct investments during the 1980s had a withering effect on MOFA sales, employment, and output of gross product, and lasted practically until 2003. The question is, whether this was due to sheer neglect, or a deliberate decision based on short-term and fleeting economic constellations in the world market, like a slowing or even recessionary demand in FDI's major markets, sharply rising cost levels overseas compared to the U.S. making further investments not only comparatively expensive, but potentially also less profitable.

Another possibility might be parent companies succumbing to official political pressures to put domestic priorities over and above their corporate plans for further expansion into the world market. There was a relative decline of MOFA shares in world trade during this period, as well as vis-a-vis U.S. exports, which may be a hint in that direction.

\section{[Table 3 is about here]}

\section{Conclusions}

The foregoing discussion introduces a novel concept for the measurement of national shares in the global output of gross domestic product (GDP), or value added. In other words, it tries to establish a more realistic measure of true national competitiveness than provided by the conventional portrayal of national economic importance based on national territory.

The formula is a straight forward three-step process as postulated in the introduction. First, take the national GDP figure published by any of the major international organizations like the UN, World Bank, OECD, etc. Second, adjust this number for the foreign factor by eliminating the output contributed by foreign capital investments active in that country's industries. Third, add the output generated by majority-owned affiliates controlled by investors from the nation under study. They may be legally part of the foreign economy, but from the capital ownership and control point-of-view they are still American, British or Japanese entities, thus enhancing the GDP of the country of origin.

Being a novel concept, it needs further methodological development, testing, and refinement. In the absence of a well developed international statistical framework, however, that would allow a more direct access to the desired information, it appears to be a workable proposition. The results presented below benefit from a vast store of pertinent statistics provided by U.S. statistical services. This may not be the case for other nations whose research results may thus become rough approximations rather than factual information.

As a realistic demonstration of the concept's usefulness, it was tested on U.S. data, which may serve as a model for other nations. The results are laid down in Table 4. They leave the American economy in a stronger position vis-a-vis the world economy than suggested by the traditional geographic definition of a nation's output of value added.

Table 4 provides the reader with a clear understanding of the three-step calculation. The first U.S. share of the world economy reiterates the information given in Table 1. This is the official situation based on the concept of "national output" within the geographic confines of the States. The first revision establishes a new share by removing the foreign-owned part of the American economy, which leads to a 1-2\% drop in the global share for the U.S. The third share calculation adds the gross product produced by American affiliates in overseas locations. Now, the American share in the global economy is elevated over and above the share data based on the "official" information provided by step one.

A clear message can be derived from the information presented here. The key to a strong position in the global 
market is not trade, but foreign direct investment. As long as a nation produces more gross product in its overseas subsidiaries, preferably the majority-owned ones, than foreign-owned affiliates crank out within its national boundaries, the stronger its position in the world economy. It may be only a matter of 1-2 percentage points, as in this case, but it is clear cut proof of that nation's competitiveness.

For other nations it may look totally different, sometimes even leading to the sad realization, that its truly domestic owned economy is significantly smaller than insinuated by traditional official statistics.

A final point has to be made, which may modify the above picture substantially for the U.S. As evident in a guide to BEA statistics on U.S. multinational companies (BEA, 1995), foreign capital participation is not clearly documented for the majority of U.S. parent companies with outward FDI affiliates. Despite this capital share, which is not quantified, they are considered to represent bona-fide American companies with FDI interests abroad, exactly like other U.S. companies without any foreign capital participation. If that assessment changes, it might lead to a reduction in U.S. capital control (FDI) over foreign business operation, but strengthen the importance of foreign capital control over U.S industries.

\section{[Table 4 is about here]}

\section{References}

BEA (Bureau of Economic Analysis). (n.d.a). International Economic Accounts. U.S. direct investment position abroad on a historical-cost basis: Country detail, 1977-79. [Online] Available: http://www.bea.gov/international/datatables/usdpos/usdpos_77.htm (July, 2010)

BEA (Bureau of Economic Analysis). (n.d.b). International Economic Accounts. Operations of multinational companies. Financial and operating data, Interactive tables, 1997-2007. [Online] Available: http://www.bea.gov/international/index.htm (July, 2010)

BEA (Bureau of Economic Analysis). (n.d.c). International Economic Accounts. Foreign direct investment in the U.S.: Financial and operating data for U.S. affiliates of foreign multinational companies, 2007. [Online] Available: http://www.bea.gov/international/dilfdiop.htm (July, 2010)

BEA (Bureau of Economic Analysis). (n.d.d). International Economic Accounts: Articles: International Investment Division Product Guide. U.S. direct investment abroad: Operations of U.S. parent companies and their foreign affiliates: Comprehensive financial and operating data: Revised estimates, 1983-2006, Part III. Majority-owned nonbank foreign affiliates of nonbank U.S. parents, Table III. A1. Selected data for foreign affiliates in all countries in which investment was reported. [Online] Available: http://www.bea.gov/scb/account_articles/international/iidguide.htm\#USDIA1 (July, 2010)

BEA (Bureau of Economic Analysis). (1983). August. Survey of Current Business, Foreign direct investment in the United States in 1982, Table 8. Foreign direct investment in the United States, selected items 1977-82, p. 35. [Online] Available: http://fraser.stlouisfed.org/publications/SCB/1983/download/15439/SCB_081983.pdf (July, 2010)

BEA (Bureau of Economic Analysis). (1991). October. Survey of Current Business. U.S. direct investment abroad: 1989 benchmark survey results, Table 1. Total assets of and sales and employment by nonbank U.S. MNC's, U.S. parents, and foreign affiliates, 1977 and 1982-89, p. 29. [Online] Available: http://fraser.stlouisfed.org/publications/SCB/1991/download/65788/SCB_101991.pdf (July, 2010)

BEA (Bureau of Economic Analysis). (1994a). February. Survey of Current Business. Gross product of U.S. multinational companies, 1977-91, Table 1. Gross product of nonbank U.S. MNC's, U.S. parents, and MOFA's, selected years, p. 43, Table 9. Structure of output for nonbank majority-owned foreign affiliates, by major area and by major industry of affiliate, 1977, 1982, 1989, and 1991, p. 54. [Online] Available: http://www.bea.gov/scb/pdf/internat/usinvest/1994/0294iid.pdf (July, 2010)

BEA (Bureau of Economic Analysis). (1994b). July. Survey of Current Business. Foreign direct investment in the United States: 1992 benchmark survey results, Table 1. Selected data of nonbank U.S. affiliates of foreign direct investors, 1977-92, p. 154. [Online] Available: http://www.bea.gov/scb/pdf/internat/fdinvest/1994/0794iid.pdf (July, 2010)

BEA (Bureau of Economic Analysis). (1995). March. Survey of Current Business. A guide to BEA statistics on U.S. Multinational companies, pp. 38-55. [Online] Available: http://bea.gov/scb/pdf/internat/usinvest/1995/0395iid.pdf (July, 2010)

BEA (Bureau of Economic Analysis). (2001). June. International Economic Accounts. Foreign direct investment in the U.S.: Final results from the 1997 benchmark survey, Table 1. Selected financial and operating data of 
nonbank U.S. affiliates of foreign companies, 1977-97, p. M-2. [Online] Available: http://www.bea.gov/international/pdf/fdius97final.pdf (July, 2010)

BEA (Bureau of Economic Analysis). (2004). August. Survey of Current Business. Operations of U.S. affiliates of foreign companies: Preliminary results from the 2002 benchmark survey, Table 18. Selected data of all nonbank and majority-owned nonbank U.S. affiliates of foreign direct investors, 1987-2002, p. 213. [Online] Available: http://www.bea.gov/scb/pdf/2004/08August/0804FDIUS.pdf (July, 2010)

BEA (Bureau of Economic Analysis). (2007). Foreign direct investment in the United States: 2004 revised estimates, Part III: Majority-owned nonbank affiliates, Table III.A 1. Selected financial and operating data of affiliates, p. 25. [Online] Available: http://www.bea.gov/international/pdf/fdius_2004/fdius04rIII_AtoC.pdf(July, 2010)

BEA (Bureau of Economic Analysis). (2008). August. Survey of Current Business. U.S. affiliates of foreign companies: Operations in 2006, Table 1. Value added and employment of majority-owned nonbank U.S. affiliates of foreign companies, 1988-2006, p. 186. [Online] Available: http://bea.gov/scb/pdf/2008/08\%20August/0808_affiliate.pdf (July, 2010)

BEA (Bureau of Economic Analysis). (2009a). July. Survey of Current Business. Direct investment positions for 2008, Table A. Direct investment positions on a historical-cost basis, 1982-2008, p. 21. [Online] Available: http://www.bea.gov/scb/pdf/2009/07\%20July/0709_dip.pdf(July, 2010)

BEA (Bureau of Economic Analysis). (2009b). August. Survey of Current Business. U.S. multinational companies: Operations in the United States and abroad in 2007, Table 1. Selected statistics for nonbank U.S. multinational companies, U.S. parents, and foreign affiliates, 1982-2007, p. 64. [Online] Available: http://www.bea.gov/scb/pdf/2009/08\%20August/0809_mnc.pdf (July, 2010)

Economic Report of the President. (2010a). National income or expenditure, Table B-10. Gross value added by sector, 1960-2009, p. 342, (Appendix B). [Online] Available: http://www.gpoaccess.gov/eop/2010/2010_erp.pdf (February, 2010)

Economic Report of the President. (2010b). Population, employment, wages, and productivity, Table B-46. Employees on nonagricultural payrolls, by major industry, 1962-2009, p. 384, (Appendix B). [Online] Available: http://www.gpoaccess.gov/eop/2010/2010_erp.pdf (February, 2010)

Economic Report of the President. (2010c). International statistics, Table B-105. U.S. international trade in goods by area, 2001-2009, p. 451, (Appendix B). [Online] Available: http://www.gpoaccess.gov/eop/2010/2010_erp.pdf (February, 2010)

World Bank. (2010a). World development indicators, GDP (Current U.S. dollars) [Online] Available: http://data.worldbank.org/indicator/NY.GDP.MKTP.CD (July, 2010)

World Bank. (2010b). World development indicators and global development finance, [Online] Available http://databank.worldbank.org/ddp/home.do (July, 2010) 
Table 1. World gross domestic product by geographical area (current US \$billion)

\begin{tabular}{|c|c|c|c|c|c|c|}
\hline Year & World Total & U.S. & Europe* & Japan & All Other & U.S. \% Share \\
\hline 1970 & 2,874 & 1,038 & 623 & 203 & 1,023 & 36.1 \\
\hline 1971 & 3,183 & 1,127 & 706 & 229 & 1,135 & 35.4 \\
\hline 1972 & 3,678 & 1,238 & 854 & 304 & 1,295 & 33.7 \\
\hline 1973 & 4,495 & 1,382 & 1,109 & 412 & 1,604 & 30.8 \\
\hline 1974 & 5,193 & 1,500 & 1,255 & 458 & 1,994 & 28.9 \\
\hline 1975 & 5,801 & 1,638 & 1,458 & 498 & 2,221 & 28.2 \\
\hline 1976 & 6,279 & 1,825 & 1,522 & 560 & 2,387 & 29.1 \\
\hline 1977 & 7,107 & 2,030 & 1,731 & 689 & 2,673 & 28.6 \\
\hline 1978 & 8,403 & 2,294 & 2,119 & 968 & 3,039 & 27.3 \\
\hline 1979 & 9,744 & 2,562 & 2,564 & 1,007 & 3,628 & 26.3 \\
\hline 1980 & 10,951 & 2,788 & 2,870 & 1,055 & 4,257 & 25.5 \\
\hline 1981 & 11,233 & 3,127 & 2,491 & 1,166 & 4,471 & 27.8 \\
\hline 1982 & 11,126 & 3,253 & 2,411 & 1,084 & 4,401 & 29.2 \\
\hline 1983 & 11,368 & 3,535 & 2,352 & 1,182 & 4,325 & 31.1 \\
\hline 1984 & 11,803 & 3,931 & 2,256 & 1,258 & 4,386 & 33.3 \\
\hline 1985 & 12,405 & 4,218 & 2,319 & 1,347 & 4,551 & 34.0 \\
\hline 1986 & 14,658 & 4,460 & 3,257 & 1,996 & 4,977 & 30.4 \\
\hline 1987 & 16,655 & 4,736 & 4,030 & 2,420 & 5,503 & 28.4 \\
\hline 1988 & 18,628 & 5,100 & 4,429 & 2,939 & 6,196 & 27.4 \\
\hline 1989 & 19,549 & 5,482 & 4,522 & 2,940 & 6,645 & 28.0 \\
\hline 1990 & 21,827 & 5,801 & 5,682 & 3,018 & 7,370 & 26.6 \\
\hline 1991 & 22,925 & 5,992 & 5,900 & 3,451 & 7,627 & 26.1 \\
\hline 1992 & 24,488 & 6,342 & 6,505 & 3,767 & 7,929 & 25.9 \\
\hline 1993 & 24,847 & 6,667 & 5,951 & 4,324 & 7,968 & 26.8 \\
\hline 1994 & 26,692 & 7,085 & 6,299 & 4,760 & 8,615 & 26.5 \\
\hline 1995 & 29,625 & 7,415 & 7,279 & 5,248 & 9,756 & 25.0 \\
\hline 1996 & 30,256 & 7,839 & 7,363 & 4,636 & 10,495 & 25.9 \\
\hline 1997 & 30,153 & 8,332 & 6,723 & 4,259 & 10,920 & 27.6 \\
\hline 1998 & 29,998 & 8,794 & 6,901 & 3,857 & 10,545 & 29.3 \\
\hline 1999 & 31,078 & 9,354 & 6,866 & 4,369 & 10,627 & 30.1 \\
\hline 2000 & 32,037 & 9,952 & 6,253 & 4,667 & 11,352 & 31.1 \\
\hline 2001 & 31,811 & 10,286 & 6,341 & 4,095 & 11,299 & 32.3 \\
\hline 2002 & 33,070 & 10,642 & 6,903 & 3,918 & 11,831 & 32.2 \\
\hline 2003 & 37,207 & 11,142 & 8,528 & 4,229 & 13,542 & 29.9 \\
\hline 2004 & 41,917 & 11,868 & 9,766 & 4,606 & 15,914 & 28.3 \\
\hline 2005 & 45,292 & 12,638 & 10,148 & 4,552 & 18,228 & 27.9 \\
\hline 2006 & 49,022 & 13,399 & 10,744 & 4,363 & 20,798 & 27.3 \\
\hline 2007 & 55,117 & 14,078 & 12,319 & 4,381 & 24,675 & 25.5 \\
\hline 2008 & 60,557 & 14,441 & 13,582 & 4,911 & 27,971 & 23.8 \\
\hline
\end{tabular}

*EMU (European Monetary Union) from 2000 forward. (Source: U.S. GDP (Economic Report of the President, 2010a); all other data (World Bank, 2010a, 2010b).) 
Table 2. Comparative aspects of U.S. outward versus inward FDI (\$billion except employment)

\begin{tabular}{|c|c|c|c|c|c|c|c|c|c|c|}
\hline \multirow[t]{2}{*}{ Year } & \multicolumn{2}{|l|}{ Position } & \multicolumn{2}{|c|}{$\begin{array}{l}\text { Employment } \\
(000)^{* *}\end{array}$} & \multicolumn{2}{|l|}{ Sales** } & \multicolumn{2}{|c|}{ Gross Product** } & \multicolumn{2}{|l|}{ Assets** } \\
\hline & Out & In & Out & In & Out & In & Out & In & Out & In \\
\hline 1977 & 146.0 & 34.6 & $7,197^{*}$ & $1,219^{*}$ & 507.0 & $194.0^{*}$ & 161.1 & $35.2^{*}$ & $490.2^{*}$ & $143.5^{*}$ \\
\hline 1982 & 207.8 & 124.7 & 5,022 & $2,448^{*}$ & 730.2 & $518.1^{*}$ & 223.7 & $103.5^{*}$ & $751.5^{*}$ & $476.4 *$ \\
\hline 1989 & 381.8 & 368.9 & 5,114 & 3,573 & $1,020.0$ & 863.5 & 320.0 & 168.5 & $1,080.2$ & $1,039.6$ \\
\hline 1990 & 430.5 & 394.9 & 5,356 & 3,842 & $1,208.3$ & 995.0 & 356.0 & 190.5 & $1,275.0$ & $1,269.9$ \\
\hline 1991 & 467.8 & 419.1 & 5,387 & 3,991 & $1,242.6$ & $1,008.4$ & 356.0 & 207.1 & $1,375.8$ & $1,396.2$ \\
\hline 1992 & 502.1 & 423.1 & 5,282 & 3,904 & $1,291.6$ & $1,049.9$ & 361.5 & 214.8 & $1,474.1$ & $1,459.5$ \\
\hline 1993 & 564.3 & 467.4 & 5,223 & 3,852 & $1,275.8$ & $1,112.7$ & 359.2 & 223.0 & $1,738.0$ & $1,625.1$ \\
\hline 1994 & 612.9 & 480.7 & 5,707 & 3,954 & $1,435.9$ & $1,210.8$ & 403.7 & 244.7 & $2,022.7$ & $1,861.8$ \\
\hline 1995 & 699.0 & 535.6 & 5,924 & 4,023 & $1,693.8$ & $1,311.2$ & 465.6 & 254.9 & $2,420.1$ & $2,039.3$ \\
\hline 1996 & 795.2 & 598.0 & 6,077 & 4,156 & $1,868.6$ & $1,423.7$ & 498.3 & 283.4 & $2,657.8$ & $2,316.9$ \\
\hline 1997 & 871.3 & 681.8 & 6,480 & 4,269 & $1,972.5$ & $1,478.2$ & 520.9 & 313.7 & $2,952.0$ & $2,661.0$ \\
\hline 1998 & $1,000.7$ & 778.4 & 6,773 & 4,670 & $1,971.9$ & $1,622.9$ & 506.3 & 353.9 & $3,389.8$ & $3,053.8$ \\
\hline 1999 & $1,216.0$ & 955.7 & 7,766 & 5,064 & $2,218.9$ & $1,792.5$ & 566.4 & 397.3 & $4,056.4$ & $3,637.3$ \\
\hline 2000 & $1,316.2$ & $1,256.9$ & 8,171 & 5,657 & $2,507.4$ & $2,051.9$ & 606.6 & 447.3 & $4,745.3$ & $4,216.3$ \\
\hline 2001 & $1,460.4$ & $1,344.0$ & 8,194 & 5,594 & $2,524.5$ & $2,070.2$ & 585.7 & 417.1 & $5,254.5$ & $4,760.6$ \\
\hline 2002 & $1,616.5$ & $1,327.2$ & 8,256 & 5,425 & $2,515.6$ & $2,031.0$ & 601.6 & 460.6 & $6,126.2$ & $4,573.1$ \\
\hline 2003 & $1,769.6$ & $1,395.2$ & 8,242 & 5,244 & $2,865.2$ & $2,122.7$ & 697.8 & 475.1 & $7,272.8$ & $5,100.8$ \\
\hline 2004 & $2,160.8$ & $1,520.3$ & 8,617 & 5,132 & $3,312.5$ & $2,292.9$ & 818.3 & 511.5 & $8,688.6$ & $5,540.4$ \\
\hline 2005 & $2,241.7$ & $1,634.1$ & 9,101 & 5,202 & $3,786.9$ & $2,509.6$ & 911.5 & 549.6 & $9,654.4$ & $5,952.1$ \\
\hline 2006 & 2477.3 & $1,840.5$ & 9,617 & 5,334 & $4,169.0$ & $2,824.1$ & $1,001.2$ & 616.3 & $11,301.2$ & $6,820.1$ \\
\hline 2007 & $2,916.9$ & $2,109.9$ & 10,017 & 5,406 & $4,736.0$ & $3,094.3$ & $1,117.6$ & 633.3 & $13,180.2$ & $8,734.9$ \\
\hline
\end{tabular}

*All nonbank affiliates. **Nonbank MOFAs data. (Source: BEA (n.d.a, n.d.b, n.d.c, n.d.d, 1983, 1991, 1994a, 2001, 2004, 2008, 2009a, 2009b).) 
Table 3. The size of U.S. outward FDI relative to the U.S. economy

\begin{tabular}{|c|c|c|c|c|c|c|}
\hline Year & $\begin{array}{l}\text { U.S. Non-ag. } \\
\text { Business GDP } \\
\text { \$billion }\end{array}$ & $\begin{array}{c}\text { Nonbank } \\
\text { MOFA GP } \\
\text { \$billion }\end{array}$ & $\%$ & $\begin{array}{l}\text { U.S. Non-ag. } \\
\text { Industrial** } \\
\text { Employment } \\
(000)\end{array}$ & $\begin{array}{c}\text { Nonbank MOFA } \\
\text { Employment } \\
(000)\end{array}$ & $\%$ \\
\hline 1977 & $1,546.5$ & 161.1 & 10.4 & 67,335 & $7,197 *$ & 10.7 \\
\hline 1982 & $2,454.5$ & 223.7 & 9.1 & 73,695 & 5,022 & 6.8 \\
\hline 1989 & $4,162.0$ & 319.9 & 7.7 & 90,087 & 5,114 & 5.7 \\
\hline 1990 & $4,376.6$ & 356.0 & 8.1 & 91,072 & 5,356 & 5.9 \\
\hline 1991 & $4,488.0$ & 356.0 & 7.9 & 89,830 & 5,387 & 6.0 \\
\hline 1992 & $4,748.9$ & 361.5 & 7.6 & 89,939 & 5,282 & 5.9 \\
\hline 1993 & $5,012.7$ & 359.2 & 7.2 & 91,855 & 5,223 & 5.7 \\
\hline 1994 & $5,341.3$ & 403.7 & 7.6 & 95,016 & 5,707 & 6.0 \\
\hline 1995 & $5,608.7$ & 465.6 & 8.3 & 97,866 & 5,924 & 6.1 \\
\hline 1996 & $5,936.9$ & 498.3 & 8.4 & 100,169 & 6,077 & 6.1 \\
\hline 1997 & $6,354.9$ & 520.9 & 8.2 & 103,112 & 6,480 & 6.3 \\
\hline 1998 & $6,731.6$ & 506.3 & 7.5 & 106,021 & 6,773 & 6.4 \\
\hline 1999 & $7,177.8$ & 566.4 & 7.9 & 108,686 & 7,766 & 7.1 \\
\hline 2000 & $7,641.9$ & 606.6 & 7.9 & 110,995 & 8,171 & 7.4 \\
\hline 2001 & $7,837.4$ & 585.7 & 7.5 & 110,708 & 8,194 & 7.4 \\
\hline 2002 & $8,060.5$ & 601.6 & 7.5 & 108,828 & 8,256 & 7.6 \\
\hline 2003 & $8,410.3$ & 697.8 & 8.3 & 108,416 & 8,242 & 7.6 \\
\hline 2004 & $8,966.4$ & 818.3 & 9.1 & 109,814 & 8,617 & 7.8 \\
\hline 2005 & $9,593.5$ & 911.5 & 9.5 & 111,899 & 9,101 & 8.1 \\
\hline 2006 & $10,191.1$ & $1,001.2$ & 9.8 & 114,112 & 9,617 & 8.4 \\
\hline 2007 & $10,672.8$ & $1,117.6$ & 10.5 & 115,380 & 10,017 & 8.7 \\
\hline
\end{tabular}

*All nonbank affiliates. **Excludes also government employees. (Source: U.S. GDP and employment data (Economic Report of the President, 2010a, 2010b); outward FDI GP and employment (BEA, n.d.b, 1991, 1994a, 2008, 2009b).) 
Table 4. U.S. share of global gross domestic product (US \$billion)

\begin{tabular}{|c|c|c|c|c|c|c|c|}
\hline Year & $\begin{array}{l}\text { World } \\
\text { Total }\end{array}$ & $\begin{array}{c}\text { Official } \\
\text { U.S. GDP }\end{array}$ & $\begin{array}{l}\text { U.S. \% } \\
\text { Share }\end{array}$ & $\begin{array}{l}\text { U.S. GDP } \\
\text { Revised* }\end{array}$ & $\begin{array}{l}\text { U.S. \% } \\
\text { Share }\end{array}$ & $\begin{array}{l}\text { U.S. GDP } \\
\text { Revised** }\end{array}$ & $\begin{array}{l}\text { True Global } \\
\text { U.S. \% Share }\end{array}$ \\
\hline 1977 & 7,107 & 2,030 & 28.6 & $1,995 * * *$ & 28.1 & 2,156 & 30.3 \\
\hline 1980 & 10,951 & 2,788 & 25.5 & $2,717 * * *$ & 24.8 & NA & NA \\
\hline 1981 & 11,233 & 3,127 & 27.8 & $3,028 * * *$ & 27.0 & NA & NA \\
\hline 1982 & 11,126 & 3,253 & 29.2 & $3,150 * * *$ & 28.3 & 3,373 & 30.3 \\
\hline 1983 & 11,368 & 3,535 & 31.1 & $3,423 * * *$ & 30.1 & 3,640 & 32.0 \\
\hline 1984 & 11,803 & 3,931 & 33.3 & $3,802 * * *$ & 32.2 & 4,022 & 34.1 \\
\hline 1985 & 12,405 & 4,218 & 34.0 & $4,083 * * *$ & 32.9 & 4,303 & 34.7 \\
\hline 1986 & 14,658 & 4,460 & 30.4 & $4,318 * * *$ & 29.5 & 4,550 & 31.0 \\
\hline 1987 & 16,655 & 4,736 & 28.4 & $4,579 * * *$ & 27.5 & 4,848 & 29.1 \\
\hline 1988 & 18,628 & 5,100 & 27.4 & 4,954 & 26.6 & 5,252 & 28.2 \\
\hline 1989 & 19,549 & 5,482 & 28.0 & 5,314 & 27.2 & 5,634 & 28.8 \\
\hline 1990 & 21,827 & 5,801 & 26.6 & 5,610 & 25.7 & 5,966 & 27.3 \\
\hline 1991 & 22,925 & 5,992 & 26.1 & 5,785 & 25.2 & 6,141 & 26.8 \\
\hline 1992 & 24,488 & 6,342 & 25.9 & 6,128 & 25.0 & 6,489 & 26.5 \\
\hline 1993 & 24,847 & 6,667 & 26.8 & 6,444 & 25.9 & 6,804 & 27.4 \\
\hline 1994 & 26,692 & 7,085 & 26.5 & 6,841 & 25.6 & 7,244 & 27.1 \\
\hline 1995 & 29,625 & 7,415 & 25.0 & 7,160 & 24.2 & 7,625 & 25.7 \\
\hline 1996 & 30,256 & 7,839 & 25.9 & 7,555 & 25.0 & 8,053 & 26.6 \\
\hline 1997 & 30,153 & 8,332 & 27.6 & 8,019 & 26.6 & 8,540 & 28.3 \\
\hline 1998 & 29,998 & 8,794 & 29.3 & 8,440 & 28.1 & 8,946 & 29.8 \\
\hline 1999 & 31,078 & 9,354 & 30.1 & 8,956 & 28.8 & 9,523 & 30.6 \\
\hline 2000 & 32,037 & 9,952 & 31.1 & 9,504 & 29.7 & 10,111 & 31.6 \\
\hline 2001 & 31,811 & 10,286 & 32.3 & 9,869 & 31.0 & 10,455 & 32.9 \\
\hline 2002 & 33,070 & 10,642 & 32.2 & 10,182 & 30.8 & 10,783 & 32.6 \\
\hline 2003 & 37,207 & 11,142 & 29.9 & 10,667 & 28.7 & 11,365 & 30.5 \\
\hline 2004 & 41,917 & 11,868 & 28.3 & 11,356 & 27.1 & 12,175 & 29.0 \\
\hline 2005 & 45,292 & 12,638 & 27.9 & 12,089 & 26.7 & 13,000 & 28.7 \\
\hline 2006 & 49,022 & 13,399 & 27.3 & 12,783 & 26.1 & 13,784 & 28.1 \\
\hline 2007 & 55,117 & 14,078 & 25.5 & 13,444 & 24.4 & 14,562 & 26.4 \\
\hline
\end{tabular}

*U.S. domestic GDP less foreign share. ${ }^{* *}$ U.S. domestic GDP less foreign FDI share plus U.S. FDI share. ***All nonbank affiliates. (Source: Computations based on data presented in Table 1, Table 2, outward FDI GP 1982-1988 (BEA, 2009b), inward FDI GP 1980-1987 (BEA, 1994b), and inward FDI GP 1988 (BEA, 2008).) 